\title{
Survival of Claviceps africana Within Sorghum Panicles at Several Texas Locations
}

Louis K. Prom, USDA-ARS, Southern Plains Agriculture Research Center, 2765 F \& B Road, College Station, TX 77845; Thomas Isakeit, Department of Plant Pathology and Microbiology, Texas A\&M University, College Station 77843; Gary N. Odvody, Texas Agricultural Experiment Station, 10345 Agnes Street, Corpus Christi 78406; Charlie M. Rush, Texas Agricultural Experiment Station, P.O. Drawer 10, Bushland 79012; Harold W. Kaufman, Texas Cooperative Extension, Route 3, Box 213AAA, Lubbock 79403; and Noe Montes, Department of Plant Pathology and Microbiology, Texas A\&M University, College Station 77843

\begin{abstract}
Prom, L. K., Isakeit, T., Odvody, G. N., Rush, C. M., Kaufman, H. W., and Montes, N. 2005. Survival of Claviceps africana within sorghum panicles at several Texas locations. Plant Dis. 89:39-43.

Survival of the sorghum ergot fungus, Claviceps africana, based on pathogenicity of recovered macroconidia used to inoculate sorghum (Sorghum bicolor), was measured in 2000 over the course of the year at five locations in Texas representing three climates. The experiment was repeated in 2001. Sphacelia associated with infected sorghum panicles were placed in nylon mesh bags and either buried at a 10-cm depth, placed on the soil surface, or suspended $61 \mathrm{~cm}$ above the ground. Samples were recovered after 4, 8, and 12 months and assessed for pathogenicity of surviving macroconidia by macerating tissue in water and spraying it onto panicles of flowering male-sterile sorghum in the greenhouse. Survival of ergot macroconidia in recovered panicles declined at all locations after the first 4 months that panicles were left in the field. The decline in viability during this period was greater in 2001 than in 2000. In 2000, survival after 4 months was greatest at Lubbock and Bushland, which have a continental steppe climate, than at the other three Texas locations, Weslaco and Corpus Christi, which have a subtropical subhumid climate, and College Station, which has a subtropical humid climate. However, this difference in survival was not as pronounced in 2001. Additionally, after 8 months, survival levels at all locations were similar. At the end of 12 months, infective macroconidia were found only at Lubbock in 2000, and only at Lubbock and College Station in 2001. Ergot macroconidia can survive in all major sorghum production areas of Texas; thus, conidia would not need to move long distances in order to initiate an epiphytotic.
\end{abstract}

Ergot is a fungal disease of sorghum (Sorghum bicolor (L.) Moench) that has its greatest impact on male-sterile lines used in hybrid seed production, with reported yield losses of up to $80 \%$ (1). However, grain sorghum hybrids can also be susceptible under environmental conditions that impede fertilization (1). After entering through the stigma of the unfertilized flower, the pathogen colonizes the ovary to form a sporulating tissue known as the sphacelium, which exudes a sticky, sugarrich fluid known as honeydew. Under humid conditions, macroconidia within the honeydew germinate to produce a short, unbranched conidiophore that bears a secondary conidium outside of the honeydew matrix (1). The secondary conidia can then become airborne. Although macroconidia can be dispersed short distances by

Corresponding author: Louis K. Prom
E-mail: lprom@cgru.usda.gov

Accepted for publication 13 August 2004.

DOI: 10.1094/PD-89-0039

This article is in the public domain and not copyrightable. It may be freely reprinted with customary crediting of the source. The American Phytopathological Society, 2005. rainsplash, secondary conidia are most probably responsible for the initiation of ergot epiphytotics, since they were the only spores found on spore traps (6).

In the Americas, ergot is caused by Claviceps africana. This disease was first observed in the United States, in Texas, in 1997 (11). In that year, it was also seen in several other states where sorghum is grown (7). Sorghum production areas of Texas account for a total of 1.1 million ha, and there are differences in the occurrence of ergot in these areas. The pathogen is endemic in south Texas (17), an area characterized by a subtropical, subhumid climate (14), with winter minimum temperatures seldom below freezing (9). In this area, ergot is not prevalent during the spring-planted crop, but fall-planted sorghum, particularly male-sterile lines, are vulnerable to ergot because of cooler, wetter weather conditions during the time of flowering. In 1998 and 2001, ergot caused a total loss of a fall-planted hybrid seed production field in this area (T. Isakeit, unpublished). During winter months, the pathogen continues to persist in an active phase on feral sorghum and johnsongrass (Sorghum halepense (L.) Pers.) (17).

In contrast to south Texas, ergot is less prevalent in the Texas Panhandle, where approximately 100,000 ha are planted for hybrid seed production, representing 85 to 95\% of U.S. seed production. An ergot epiphytotic, affecting hybrid seed production fields, caused widespread economic loss in the Texas Panhandle in 1997, but in the subsequent 3 years, ergot occurred at low levels (24). In contrast with south Texas, this northern part of the state has a continental steppe climate, characterized by a lower relative humidity and rainfall (14). Minimum temperatures are frequently below freezing for much of the winter (9).

The survival propagules of $C$. africana are macroconidia, either in honeydew or associated with sphacelia and sclerotia. Sclerotia differentiate from sphacelia, but this does not consistently occur in all regions where ergot is present. Sclerotial development from sphacelia has been observed during the late fall in some years in southernmost Texas (18), but not further north in the Corpus Christi area, because high humidity during winter months promotes saprophytic colonization of sphacelia before they can differentiate into sclerotia (17). Weather conditions in the Texas Panhandle during the fall have supported sclerotial development (18). Sclerotia do not germinate readily to produce ascomata (5), so ascospores are not likely important in the epidemiology of ergot in Texas. The survivability of $C$. africana sclerotia is not known. However, sclerotia of other Claviceps species are not longlived. Cunfer and Seckinger (4) noted that sclerotia of $C$. purpurea survived for 6 months at most, while sclerotia of $C$. paspali survived for 14 months under field conditions in Georgia.

In Zimbabwe, viability of macroconidia associated with sphacelia decreased substantially between cropping seasons, during a time of high temperatures and rainy weather (8). Survival of macroconidia on leather, paper, metal, plastic, and rubber decreased by nearly $50 \%$ from December to May under natural field conditions in Kansas and Mexico (3). Jensen (12) reported that ergot conidia placed on the ground in Nebraska survived from November 1997 to May 1998.

In Queensland, Australia, conidia on infected panicles survived 7.5 weeks in summer months and 12 weeks during win- 
ter months, 4 weeks when buried in soil, and 19 to 27 weeks when on the soil surface (2). However, recent studies using amplified fragment length polymorphism, radiolabeled DNA amplification fingerprints, and random amplified polymorphic DNA analysis have shown that Australian isolates of $C$. africana are genetically different from those present in the Americas $(13,20,23)$. These genetic differences could be reflected in phenotypic differences in sorghum ergot between the two continents. Thus, there may be differences in survivability of isolates from the two continents.

The objective of this research was to measure the seasonal survival and viability of $C$. africana macroconidia, associated with infected sorghum panicles, in five different locations in Texas, representing three different climates. The storage methods simulate dead, standing plants, as well as plants plowed under or lying on top of soil.

\section{MATERIALS AND METHODS}

Preparation of infected panicles. Ergot-infected panicles of the male-sterile sorghum line 'ATx623' were collected from plots at the Texas Agricultural Experiment Station in Weslaco during the first week of January in each year the experiment was conducted (2000 and 2001). Panicles (inflorescences) were chosen for a high incidence of infection ( $>75 \%$ infected florets) and recent infection, as indicated by the absence of saprophytic colonization of honeydew. Ten to $12 \mathrm{~g}$ of infected panicles were sealed in $8 \mathrm{~cm}^{2}$, black, nylon mesh bags with a $1.25 \mathrm{~mm}^{2}$ mesh size.

Locations. In both years, the experiments were conducted at Texas A\&M University agricultural experiment stations located in Weslaco, Corpus Christi, College Station (Burleson County), Lubbock, and Bushland. At each station, there were three replications (sites) where bags were left. At these sites, there were three types of placement: buried at a $10-\mathrm{cm}$ depth, placed on the soil surface, and suspended $61 \mathrm{~cm}$ above the ground. Bags on or above the soil surface were protected from birds and rodents with wire cages that allowed for exposure to the environment.

The soil types at the stations were as follows: Weslaco, Hidalgo sandy clay loam (fine loamy, mixed, hyperthermic, Typic Calciustolls); Corpus Christi, Victoria clay (fine, montmorillonitic, hyperthermic, Udic Pellusterts); College Station, Weswood silt loam (fine, silty mixed [calcareous] thermic, Typic Udifluvent); Lubbock, Olton clay loam (fine, mixed, thermic, Aridic Paleustolls); Bushland, Pullman clay loam (fine, mixed, thermic, Torrertic Paleustolls). Weather stations at the locations provided hourly measurements of air temperature at $1 \mathrm{~m}$, soil temperature at 10 $\mathrm{cm}$ depth, and precipitation.

Assessment of survival. Survival was based on the infectivity of propagules recovered from samples containing ergotinfected florets. Nine sample bags (three from each placement) from each location were collected at each sampling time. Samples from all five locations were collected at 4, 8, and 12 months after placement (May, September, and the following January) and assessed for survival within 1 or 2 days after collection. The plant residue from each bag was placed in a beaker with $100 \mathrm{ml}$ of sterile distilled water, soaked for $1 \mathrm{~h}$, and then macerated for 1 min with a Waring blender (Waring Commercial, New Hartford, CT). The suspension was filtered through several layers of cheesecloth, and $10 \mu \mathrm{l}$ of Tween 20 was added. The panicles of three greenhousegrown sorghum plants ('ATx623') at full bloom were sprayed until runoff with the suspension obtained from each bag. The inoculated panicles were covered with paper bags for $24 \mathrm{~h}$ and then misted twice daily for four consecutive days to enhance infection and symptom development. As a negative control, panicles were sprayed with sterile distilled water and, as a positive control, panicles were inoculated with a conidial suspension obtained from stored $\left(4^{\circ} \mathrm{C}\right)$, infected panicles. Inoculated plants were placed in a greenhouse with a temperature of $25^{\circ} \mathrm{C}\left( \pm 2^{\circ} \mathrm{C}\right)$ and 40 to $90 \%$ relative humidity. Lighting was supplemented with a 12-h photoperiod from a 400 W high-pressure sodium lamp. Disease incidence and severity were determined 14 to 20 days after inoculation. Disease development did not change during this time interval. Ergot severity was based on the number of infected florets divided by the total number of florets per panicle then multiplied by 100 . Honeydew was examined microscopically to confirm the presence of $C$. africana conidia.

Statistical analysis. At each sampling time, the mean for disease incidence and severity was based on the assessment of nine inoculated panicles for each type of placement (buried, on soil surface, or aboveground) from each location. Data for the 2 years on incidence and percent ergot severity were analyzed separately using PROC MIXED (SAS version 8.1, SAS Institute, Cary, NC) to determine the effects of the fixed factors, placement, and sampling time (i.e., retrieval at 4, 8, and 12 months) and their interactions for each location. Location was considered as a random effect. The random factors included replication and plant within placement by replication. Differences among placements within each sampling time were determined by pairwise comparisons of least square means with $t$ tests. The Pearson correlation coefficient was calculated between survival and weather pa-

Table 1. Survival of Claviceps africana macroconidia in sorghum panicles at five Texas locations in 2000 and 2001 as measured by their ability to infect susceptible sorghum plants in the greenhouse ${ }^{\mathrm{w}}$

\begin{tabular}{|c|c|c|c|c|c|c|c|c|c|}
\hline \multirow[b]{2}{*}{ Location } & \multirow[b]{2}{*}{ Year } & \multirow[b]{2}{*}{ Placement $^{\mathrm{x}}$} & \multicolumn{3}{|c|}{ Sampling time } & \multirow[b]{2}{*}{ Year } & \multicolumn{3}{|c|}{ Sampling time } \\
\hline & & & 4 & 8 & 12 & & 4 & 8 & 12 \\
\hline \multirow[t]{3}{*}{ Bushland } & 2000 & Above & $100.0 \mathrm{a}^{\mathrm{y}}$ & $88.9 \mathrm{a}$ & $\mathrm{M}^{\mathrm{z}}$ & 2001 & $100.0 \mathrm{a}$ & $55.6 \mathrm{a}$ & $0.0 \mathrm{a}$ \\
\hline & & Soil surface & $88.9 \mathrm{a}$ & $22.2 \mathrm{~b}$ & M & & $88.9 \mathrm{a}$ & $22.2 \mathrm{~b}$ & $0.0 \mathrm{a}$ \\
\hline & & Buried & $33.3 \mathrm{~b}$ & $0.0 \mathrm{c}$ & M & & $44.5 \mathrm{~b}$ & $0.0 \mathrm{c}$ & $0.0 \mathrm{a}$ \\
\hline \multirow[t]{3}{*}{ Corpus Christi } & 2000 & Above & $100.0 \mathrm{a}$ & $55.6 \mathrm{a}$ & $0.0 \mathrm{a}$ & 2001 & $88.9 \mathrm{a}$ & $0.0 \mathrm{a}$ & $0.0 \mathrm{a}$ \\
\hline & & Soil surface & $100.0 \mathrm{a}$ & $22.2 \mathrm{~b}$ & $0.0 \mathrm{a}$ & & $44.5 \mathrm{~b}$ & $0.0 \mathrm{a}$ & $0.0 \mathrm{a}$ \\
\hline & & Buried & $88.9 \mathrm{~b}$ & $0.0 \mathrm{c}$ & $0.0 \mathrm{a}$ & & $11.1 \mathrm{c}$ & $0.0 \mathrm{a}$ & $0.0 \mathrm{a}$ \\
\hline \multirow{3}{*}{ College Station } & 2000 & Above & $100.0 \mathrm{a}$ & $48.1 \mathrm{a}$ & $0.0 \mathrm{a}$ & 2001 & $66.7 \mathrm{a}$ & $0.0 \mathrm{a}$ & $0.0 \mathrm{~b}$ \\
\hline & & Soil surface & $11.1 \mathrm{~b}$ & $55.6 \mathrm{a}$ & $0.0 \mathrm{a}$ & & $11.1 \mathrm{~b}$ & $0.0 \mathrm{a}$ & $0.0 \mathrm{~b}$ \\
\hline & & Buried & $0.0 \mathrm{~b}$ & $0.0 \mathrm{~b}$ & $0.0 \mathrm{a}$ & & $22.2 \mathrm{~b}$ & $0.0 \mathrm{a}$ & $22.2 \mathrm{a}$ \\
\hline \multirow[t]{3}{*}{ Lubbock } & 2000 & Above & $100.0 \mathrm{a}$ & $100.0 \mathrm{a}$ & $22.2 \mathrm{a}$ & 2001 & $88.9 \mathrm{a}$ & $33.3 \mathrm{a}$ & $11.1 \mathrm{a}$ \\
\hline & & Soil surface & $77.8 \mathrm{~b}$ & $22.2 \mathrm{~b}$ & $0.0 \mathrm{~b}$ & & $55.6 \mathrm{~b}$ & $0.0 \mathrm{~b}$ & $11.1 \mathrm{a}$ \\
\hline & & Buried & $11.1 \mathrm{c}$ & $11.1 \mathrm{~b}$ & $11.1 \mathrm{ab}$ & & $22.2 \mathrm{c}$ & $11.1 \mathrm{~b}$ & $0.0 \mathrm{a}$ \\
\hline \multirow[t]{3}{*}{ Weslaco } & 2000 & Above & $100.0 \mathrm{a}$ & $88.9 \mathrm{a}$ & $0.0 \mathrm{a}$ & 2001 & $88.9 \mathrm{a}$ & $0.0 \mathrm{~b}$ & $0.0 \mathrm{a}$ \\
\hline & & Soil surface & $77.8 \mathrm{~b}$ & $55.6 \mathrm{~b}$ & $0.0 \mathrm{a}$ & & $44.5 \mathrm{~b}$ & $33.3 \mathrm{a}$ & $0.0 \mathrm{a}$ \\
\hline & & Buried & $66.7 \mathrm{~b}$ & $55.6 \mathrm{~b}$ & $0.0 \mathrm{a}$ & & $11.1 \mathrm{c}$ & $0.0 \mathrm{~b}$ & $0.0 \mathrm{a}$ \\
\hline
\end{tabular}

${ }^{w}$ Values are percent disease incidence of nine greenhouse-grown sorghum panicles per placement sprayed with a suspension of recovered propagules.

${ }^{x}$ Placement sites of infected panicles: $61 \mathrm{~cm}$ above the ground, on soil surface, buried $10 \mathrm{~cm}$ below soil surface.

${ }^{y}$ Means within a sampling time (months after placement) per year (per location) with the same letter(s) are not significantly different at the 5\% probability level based on $t$ tests of least squares means.

${ }^{\mathrm{z}} \mathrm{M}=$ missing value. 
rameters. For the analysis, weather values were averaged or summed at 4,8 , and 12 months. Soil temperatures were correlated only with disease incidence from buried samples.

\section{RESULTS}

Disease incidence. Placement and sampling time main effects and placement $\times$ sampling time interactions significantly $(P$ $<0.001$ ) affected the survival (measured as disease incidence) of ergot macroconidia in recovered panicles at all locations in both years, except for placement $\times$ sampling time interaction at Weslaco in 2000, which was significant at $P<0.0261$, and for placement at College Station $(P<$ $0.0030)$ in 2001. No ergot infection was observed on the negative controls in any inoculation. The positive controls exhibited $100 \%$ disease incidence in both years. Disease incidence ranged from 0 to $100 \%$ across locations at 4 months in 2000 (Table 1). At 4 months, disease incidence from samples retrieved from aboveground was significantly higher than for those samples collected from soil-surface or buried in College Station, Lubbock, and Weslaco. Except for College Station, ergot incidence from samples collected aboveground at 8 months was significantly greater than for the other two placement treatments. No macroconidia survived at 12 months in Corpus Christi, College Station, and Weslaco. In 2001, disease incidence on inoculated plants ranged from 11.1 to $100 \%$ at 4 months, and ergot incidences from the aboveground samples were significantly $(P<0.05)$ higher than incidences from soil-surface and buried samples in Corpus Christi, College Station, Lubbock, and Weslaco. At 8 months, disease incidence ranged from 0 to $55.6 \%$. No macroconidia survived after 4 months in Corpus Christi and after 8 months in Bushland and Weslaco. At the end of 12 months, infective macroconidia were found only at Lubbock in 2000 (data for
Bushland is missing), and only in Lubbock and College Station in 2001.

Disease severity. Survival of ergot macroconidia in recovered panicles, measured as the ability to infect susceptible sorghum in the greenhouse, was significantly affected by placement $(P \leq 0.05)$, sampling time, and placement $\times$ sampling time interactions $(P<0.01)$ at Bushland, Corpus Christi, College Station, and Lubbock in both years (Table 2). Significant placement $\times$ sampling time interactions indicate that survival at each placement level was not the same at each sampling interval. In 2000, macroconidia survival in Weslaco was not affected by placement and placement $\times$ sampling time interactions.

Ergot severity on the positive controls ranged from 65 to $90 \%$, with a mean of $80.1 \%$ in 2000 and from 50 to $90 \%$, with a mean of $80.2 \%$, in 2001 . At 4 months, the mean ergot severity from aboveground samples was significantly $(P<0.05)$ higher than from soil-surface or buried samples, except for Corpus Christi in 2000 (Table 3). In 2000, the highest ergot severities of 69.8 and $61 \%$ were from 4-monthold, aboveground samples from Bushland and Lubbock, respectively. In all locations, ergot severity was greater in 2000 than in 2001. Macroconidia from buried panicles generally declined faster than macroconidia from panicles lying on the ground. In both years, one location had at least one buried panicle with infective macroconidia at the end of 12 months: Lubbock in both years, and College Station in 2001. Differences in ergot severity were not significant among samples collected after 8 and 12 months in all locations, irrespective of placement.

Survival and weather. Generally, ergot survival (measured as incidence) was negatively correlated with temperature and precipitation (Table 4). These correlations were significant for at least some of the weather parameters at all locations except College Station and Lubbock in 2000.

\section{DISCUSSION}

Survival and pathogenicity of the macroconidia associated with infected sorghum panicles was assessed at five locations in Texas in two separate years by inoculation of a male-sterile sorghum, which is highly susceptible to $C$. africana. Although viability had greatly declined at all locations, at the end of 12 months, there were still infective macroconidia in some locations, which represent different climates. With an 8-month gap between harvest and flowering of a new crop, it is possible for the fungus to overwinter in all these sorghum production areas of Texas, and therefore, it is conceivable that epiphytotics can be initiated from inoculum of local origin in all locations. Inoculum can be associated with crop debris rather than living hosts such as johnsongrass or feral sorghum. Frederickson et al. (6) had shown experimentally in Zimbabwe that airborne spores of $C$. africana could move at least $300 \mathrm{~m}$ from secondary conidia generated from a few infected panicles. Our study suggests that burying panicles (e.g., by moldboard plowing) could substantially reduce inoculum. Viability was also reduced with buried panicles in an Australian study (2).

Cool weather (average daily temperature $<10^{\circ} \mathrm{C}$ ) supports survival of conidia. In Australia, survival on panicles was longer during the cooler winter months than during the summer months (2). In our study, we compared survival in three different climates. With a 2-year study, we were able to observe the effect of variation in the weather of these climates on survival. In our study, we chose to simultaneously place uniformly produced inoculum in these five locations, to eliminate differences in inoculum potential originating from sphacelial development at different locations. Conidia in panicles were exposed to the weather of these locations for a full year, but in our study, panicles in the Lubbock and Bushland locations initially

Table 2. Effect of placement and sampling time on Claviceps africana macroconidia survival measured as disease severity on greenhouse-grown sorghum line ATx623 in 2000 and 2001 at five locations in Texas ${ }^{\mathrm{z}}$

\begin{tabular}{|c|c|c|c|c|c|c|c|c|c|c|c|}
\hline Location & Year & Factor & $\underset{\text { df }}{\text { Num }}$ & $\begin{array}{c}\text { Den } \\
\text { df }\end{array}$ & $F$ value & $P>F$ & Year & $\underset{\text { df }}{\text { Num }}$ & $\begin{array}{c}\text { Den } \\
\text { df }\end{array}$ & $F$ value & $P>F$ \\
\hline \multirow[t]{3}{*}{ Bushland } & 2000 & Placement & 2 & 46 & 46.75 & $<0.0001$ & 2001 & 2 & 72 & 40.95 & $<0.0001$ \\
\hline & & Sampling time (ST) & 2 & 46 & 87.17 & $<0.0001$ & & 2 & 72 & 61.69 & $<0.0001$ \\
\hline & & Placement $\times \mathrm{ST}$ & 4 & 46 & 37.43 & $<0.0001$ & & 4 & 72 & 38.07 & $<0.0001$ \\
\hline \multirow[t]{3}{*}{ Corpus Christi } & 2000 & Placement & 2 & 70 & 8.86 & 0.0004 & 2001 & 2 & 70 & 10.63 & $<0.0001$ \\
\hline & & Sampling time (ST) & 2 & 70 & 67.31 & $<0.0001$ & & 2 & 70 & 13.49 & $<0.0001$ \\
\hline & & Placement $\times$ ST & 4 & 70 & 8.15 & $<0.0001$ & & 4 & 70 & 10.63 & $<0.0001$ \\
\hline \multirow[t]{3}{*}{ College Station } & 2000 & Placement & 2 & 70 & 9.33 & 0.0144 & 2001 & 2 & 70 & 4.77 & 0.0114 \\
\hline & & Sampling time (ST) & 2 & 70 & 17.87 & $<0.0001$ & & 2 & 70 & 5.43 & 0.0064 \\
\hline & & Placement $\times \mathrm{ST}$ & 4 & 70 & 16.75 & $<0.0001$ & & 4 & 70 & 4.91 & 0.0015 \\
\hline \multirow[t]{3}{*}{ Lubbock } & 2000 & Placement & 2 & 70 & 72.29 & $<0.0001$ & 2001 & 2 & 22 & 10.92 & 0.0005 \\
\hline & & Sampling time (ST) & 2 & 70 & 89.49 & $<0.0001$ & & 2 & 48 & 14.67 & $<0.0001$ \\
\hline & & Placement $\times$ ST & 4 & 70 & 57.12 & $<0.0001$ & & 4 & 48 & 7.85 & $<0.0001$ \\
\hline \multirow[t]{3}{*}{ Weslaco } & 2000 & Placement & 2 & 72 & 2.44 & 0.0939 & 2001 & 2 & 70 & 7.35 & 0.0013 \\
\hline & & Sampling time (ST) & 2 & 72 & 7.77 & 0.0009 & & 2 & 70 & 18.51 & $<0.0001$ \\
\hline & & Placement $\times$ ST & 4 & 72 & 1.83 & 0.1316 & & 4 & 70 & 7.74 & $<0.0001$ \\
\hline
\end{tabular}

\footnotetext{
${ }^{\mathrm{z}}$ Placement $=$ samples placed above ground, soil surface, and buried and sampling time=time bags containing infected panicles were retrieved from the
} locations $(4,8$, and 12 months). 
encountered low winter temperatures rather than the higher temperatures that can occur there in the fall following harvest. Since exposure to higher temperatures decreases viability of macroconidia (8), we possibly underestimated the rate of loss of viability in Bushland and Lubbock. It is likely that in the fall, soil temperatures in these locations are high enough to foster a decline in viability.

We looked at the simultaneous placement of diseased panicles with conidia at different locations. Placement of conidia at the time of each harvest, which differs in these growing areas, would mimic the environmental conditions that they are exposed to. Our design simulated the fate of crop residue following harvest of a fall crop in Weslaco, south Texas. If a spring crop is planted, it flowers in May. Our experiments show that conidia can survive within this time frame. In comparison, a sorghum crop in Bushland would flower in August and conidia would need to survive for a longer period of time, but this can also occur. In contrast, in Zimbabwe, inoculum must survive 6 months, until flowering in the next growing season, from June to January. However, macroconidia associated with sphacelia declined in viability because of the moisture and high temperatures of the rainy season (8).

The location of the macroconidia in a field is an important determinant in their survival. In this study, macroconidia left aboveground had the highest levels of viability. This agrees with an Australian study, where viability of conidia within panicles was maintained longer when panicles were left aboveground than when they were buried (2). Reduction of viability of buried conidia could be attributed to a longer duration of exposure to moisture, as well as to antagonism by soil microflora. Soil temperature would be an important factor determining the level of microbial activity (19).

Persistence of honeydew may be a factor in the survival of macroconidia within it. Mower et al. (16) and Mantle et al. (15) noted that some honeydew sugars produced by $C$. africana prevent conidial germination, particularly under adverse conditions, thus contributing to preservation. Honeydew sugars would not likely persist in soil, as they are readily degradable by soil microflora (19).

In south Texas, survival of the pathogen in crop debris is not necessary, since the pathogen can overwinter as an active infec-

Table 3. Survival of Claviceps africana propagules in sorghum panicles at five Texas locations in 2000 and 2001 as measured by ergot severity on inoculated susceptible sorghum plants in the greenhouse ${ }^{w}$

\begin{tabular}{|c|c|c|c|c|c|c|c|c|c|}
\hline \multirow[b]{2}{*}{ Location } & \multirow[b]{2}{*}{ Year } & \multirow[b]{2}{*}{ Placement $^{x}$} & \multicolumn{3}{|c|}{ Sampling time } & \multirow[b]{2}{*}{ Year } & \multicolumn{3}{|c|}{ Sampling time } \\
\hline & & & 4 & 8 & 12 & & 4 & 8 & 12 \\
\hline \multirow[t]{3}{*}{ Bushland } & 2000 & Above & $69.8 \mathrm{a}^{\mathrm{y}}$ & $3.6 \mathrm{a}$ & $\mathrm{M}^{\mathrm{z}}$ & 2001 & $26.8 \mathrm{a}$ & $0.7 \mathrm{a}$ & $0.0 \mathrm{a}$ \\
\hline & & Soil surface & $21.8 \mathrm{~b}$ & $0.2 \mathrm{a}$ & M & & $3.8 \mathrm{~b}$ & $0.3 \mathrm{a}$ & $0.0 \mathrm{a}$ \\
\hline & & Buried & $0.6 \mathrm{c}$ & $0.0 \mathrm{a}$ & M & & $0.8 \mathrm{~b}$ & $0.0 \mathrm{a}$ & $0.0 \mathrm{a}$ \\
\hline \multirow[t]{3}{*}{ Corpus Christi } & 2000 & Above & $25.0 \mathrm{a}$ & $0.7 \mathrm{a}$ & $0.0 \mathrm{a}$ & 2001 & $8.6 \mathrm{a}$ & $0.0 \mathrm{a}$ & $0.0 \mathrm{a}$ \\
\hline & & Soil surface & $21.0 \mathrm{a}$ & $0.1 \mathrm{a}$ & $0.0 \mathrm{a}$ & & $0.4 \mathrm{~b}$ & $0.0 \mathrm{a}$ & $0.0 \mathrm{a}$ \\
\hline & & Buried & $5.4 \mathrm{~b}$ & $0.0 \mathrm{a}$ & $0.0 \mathrm{a}$ & & $0.3 \mathrm{~b}$ & $0.0 \mathrm{a}$ & $0.0 \mathrm{a}$ \\
\hline \multirow[t]{3}{*}{ College Station } & 2000 & Above & $11.6 \mathrm{a}$ & $0.3 \mathrm{a}$ & $0.0 \mathrm{a}$ & 2001 & $9.1 \mathrm{a}$ & $0.0 \mathrm{a}$ & $0.0 \mathrm{a}$ \\
\hline & & Soil surface & $0.9 \mathrm{~b}$ & $1.3 \mathrm{a}$ & $0.0 \mathrm{a}$ & & $0.2 \mathrm{~b}$ & $0.0 \mathrm{a}$ & $0.0 \mathrm{a}$ \\
\hline & & Buried & $0.0 \mathrm{~b}$ & $0.0 \mathrm{a}$ & $0.0 \mathrm{a}$ & & $0.2 \mathrm{~b}$ & $0.0 \mathrm{a}$ & $0.2 \mathrm{a}$ \\
\hline \multirow[t]{3}{*}{ Lubbock } & 2000 & Above & $61.0 \mathrm{a}$ & $4.7 \mathrm{a}$ & $0.1 \mathrm{a}$ & 2001 & $11.2 \mathrm{a}$ & $0.6 \mathrm{a}$ & $0.9 \mathrm{a}$ \\
\hline & & Soil surface & $9.3 \mathrm{~b}$ & $0.1 \mathrm{a}$ & $0.0 \mathrm{a}$ & & $2.0 \mathrm{~b}$ & $0.0 \mathrm{a}$ & $0.1 \mathrm{a}$ \\
\hline & & Buried & $0.3 \mathrm{c}$ & $0.03 \mathrm{a}$ & $0.1 \mathrm{a}$ & & $0.4 \mathrm{~b}$ & $0.1 \mathrm{a}$ & $0.0 \mathrm{a}$ \\
\hline \multirow[t]{3}{*}{ Weslaco } & 2000 & Above & 15.5 & 2.1 & 0.0 & 2001 & $6.4 \mathrm{a}$ & $0.0 \mathrm{a}$ & $0.0 \mathrm{a}$ \\
\hline & & Soil surface & 4.3 & 0.4 & 0.0 & & $2.2 \mathrm{~b}$ & $0.4 \mathrm{a}$ & $0.0 \mathrm{a}$ \\
\hline & & Buried & 4.2 & 1.5 & 0.0 & & $0.2 \mathrm{c}$ & $0.0 \mathrm{a}$ & $0.0 \mathrm{a}$ \\
\hline
\end{tabular}

${ }^{\text {w}}$ Values are percent disease severity of nine greenhouse-grown panicles of sorghum line 'ATx623' per placement sprayed with a suspension of recovered propagules.

${ }^{x}$ Placement sites of infected panicles: $61 \mathrm{~cm}$ above the ground, on soil surface, buried $10 \mathrm{~cm}$ below soil surface.

${ }^{y}$ Means within a sampling time (months after placement) per year (per location) with the same letter(s) are not significantly different at the $5 \%$ probability level based on $t$ tests of least squares means.

${ }^{\mathrm{z}} \mathrm{M}=$ missing data.

Table 4. Correlation coefficients between ergot survival (percent disease incidence) and weather parameters during the 2000 and 2001 experiments conducted in five Texas locations ${ }^{w}$

\begin{tabular}{|c|c|c|c|c|c|c|c|c|c|c|c|c|c|}
\hline \multirow[b]{2}{*}{ Location } & \multirow[b]{2}{*}{ Year } & \multicolumn{2}{|c|}{$\operatorname{Tavg}^{x}$} & \multicolumn{2}{|c|}{ Tmax } & \multicolumn{2}{|c|}{ Tmin } & \multicolumn{2}{|c|}{ Tsoil } & \multicolumn{2}{|c|}{ Pavg } & \multicolumn{2}{|c|}{ Pcum } \\
\hline & & $r$ & $P$ & $r$ & $P$ & $r$ & $\boldsymbol{P}$ & $r$ & $\boldsymbol{P}$ & $r$ & $P$ & $r$ & $P$ \\
\hline Bushland & 2001 & -0.77642 & $139^{* * \mathrm{y}}$ & -0.78620 & $120^{* * *}$ & .76820 & $0156^{* *}$ & .99994 & $0.0068^{* * * *}$ & 0.04635 & 0.9057 & -0.84042 & $0.0046^{* * * *}$ \\
\hline $\begin{array}{l}\text { Corpus } \\
\text { Christi }\end{array}$ & 2000 & -0.78399 & $0.0124^{* *}$ & -0.77464 & $0.0142^{* *}$ & -0.77912 & $0.0133^{* *}$ & -0.94722 & 0.2078 & -0.81292 & $0.0077^{* * * *}$ & -0.88166 & $0.0017^{* * *}$ \\
\hline $\begin{array}{l}\text { Corpus } \\
\text { Christi }\end{array}$ & 2001 & -0.77075 & $0.0151^{* *}$ & -0.77091 & $0.0150^{* *}$ & -0.77195 & $0.0148^{* *}$ & -0.99662 & 0.0524 & -0.73221 & $0.0249^{* *}$ & -0.66281 & 0.0517 \\
\hline $\begin{array}{l}\text { College } \\
\text { Station }\end{array}$ & 2000 & -0.21719 & 0.5746 & -0.18322 & 0.6370 & -0.17997 & 0.6431 & -0.25699 & 0.5044 & -0.33806 & 0.3736 & -0.51689 & 0.1542 \\
\hline $\begin{array}{l}\text { College } \\
\text { Station }\end{array}$ & 2001 & -0.68324 & $0.0425^{* *}$ & -0.68022 & $0.0438^{* * *}$ & -0.68460 & $0.0419^{* *}$ & -0.68460 & 0.5222 & -0.56869 & 0.1101 & -0.49825 & 0.1722 \\
\hline Lubbock & 2000 & 30958 & 0. & .25766 & 0 & -0.34644 & 0. & $\mathrm{M}^{\mathrm{z}}$ & & -0.38113 & 0.3115 & -0.51716 & 0.1539 \\
\hline Lubbock & 2001 & -0.73417 & $0.0243^{* *}$ & -0.73527 & $0.0240^{* *}$ & -0.73254 & $0.0248^{* *}$ & -0.81706 & 0.3912 & -0.60186 & 0.0864 & -0.74930 & $0.0201^{\text {** }}$ \\
\hline Weslaco & 2000 & -0.27720 & 0.4702 & -0.27720 & 0.4702 & -0.27720 & 0.4702 & -0.32784 & 0.7874 & -0.60530 & 0.0841 & -0.86076 & $0.0029^{* * *}$ \\
\hline Weslaco & 2001 & -0.66778 & $0.0493^{* *}$ & -0.67276 & $0.0471^{* *}$ & -0.66972 & $0.0484^{* *}$ & -0.06951 & 0.9557 & 0.69008 & $0.0397^{* *}$ & -0.69217 & $0.0388^{* *}$ \\
\hline
\end{tabular}

${ }^{\text {w}}$ Survival of Claviceps africana propagules in sorghum panicles following placement in fields for 12 months in 2000 and 2001 as measured by their ability to infect susceptible sorghum plants in the greenhouse. Correlation analysis was not conducted for Bushland in 2000 because of missing values.

${ }^{\times}$Tavg = average temperature; $\operatorname{Tmax}=$ maximum daily temperature; $\operatorname{Tmin}=$ minimum daily temperature; Tsoil = soil temperature; Pavg = average daily precipitation; and Pcum $=$ cumulative precipitation .

$\mathrm{y}^{* * *}$ or $^{* * *}$ denotes significance at 5 or $1 \%$ probability level.

${ }^{\mathrm{z}} \mathrm{M}=$ missing values. 
tion on feral sorghum or johnsongrass (17). Additionally, there are other potential sources of inoculum available to initiate an epiphytotic. The corn earworm moth, Helicoverpa zea, is capable of transmitting conidia of $C$. africana from infected to healthy sorghum plants (22). The conidia can survive at least 3 days in the guts of insects (21).

We measured the infectivity of recovered macroconidia, rather than just their germinability, as was done in the study of Bhuiyan et al. (2). Although we found the percentage of panicles containing infective macroconidia was as high as $100 \%$ for the first 8 months of the study, the quantity or quality of macroconidia from these panicles could initiate only low disease severity. For example, $100 \%$ of aboveground panicles in Lubbock in 2000 had infective macroconidia at 8 months but resulted in a range of 1 to $25 \%$ disease severity of inoculated florets, as compared with 50 to $90 \%$ severity using macroconidia obtained from panicles stored at $4^{\circ} \mathrm{C}$. We felt that a measurement of infectivity was a more critical assessment of survival than viability, since the epiphytotic cannot be initiated until plants are infected. Macroconidia exposed to the soil environment may be affected by soil fungistasis, and one of the consequences can be a reduction in endogenous nutrient reserves, which can result in a loss of virulence prior to a loss in viability (10). There is no information about whether this occurs with spores of $C$. africana and, if it does, what length of burial time is required.

This study shows that ergot macroconidia can survive in all major sorghum production areas of Texas. Therefore, it can be concluded that inoculum does not need to move long distances in order to initiate an epiphytotic. Reduced tillage practices could contribute to the overwintering of inoculum, but reduced tillage is not generally utilized for sorghum production in Texas. However, overwintering of ergot in standing panicles of dead feral sorghum or johnsongrass around sorghum fields could contribute local inoculum.
Controlled environmental studies can better elucidate the exact temperature and moisture conditions that affect $C$. africana survival in such inoculum.

\section{ACKNOWLEDGMENTS}

We thank Joseph P. Krausz for his input in conducting this research, and Abdourhamane Issoufou Kollo, Gurudev Mayalagu, and Jonathan Egilla for technical assistance.

\section{LITERATURE CITED}

1. Bandyopadhyay, R., Frederickson, D. E., McLaren, N. W., Odvody, G. N., and Ryley, M. J. 1998. Ergot: A new disease threat to sorghum in the Americas and Australia. Plant Dis. 82:356-367.

2. Bhuiyan, S. A., Ryley, M. J., Galea, V. J., Tay, D., and Lisle, A. T. 2002. Survival of conidia of sorghum ergot (caused by Claviceps africana) on panicles, seed and soil in Australia. Aust. Plant Pathol. 31:137-141.

3. Claflin, L. E., and Ramundo, B. A. 1999. Overwintering survival of Claviceps africana, causal agent of ergot disease of grain sorghum. (Abstr.) Phytopathology 89:S16

4. Cunfer, B. M., and Seckinger, A. 1977. Survival of Claviceps purpurea and C. paspali sclerotia. Mycologia 69:1142-1148.

5. Frederickson, D. E., Mantle, P. G., and de Milliano, W. A. J. 1991. Claviceps africana sp. nov., the distinctive ergot pathogen of sorghum in Africa. Mycol. Res. 95:1101-1107.

6. Frederickson, D. E., Mantle, P. G., and de Milliano, W. A. J. 1993. Windborne spread of ergot disease (Claviceps africana) in sorghum A-lines in Zimbabwe. Plant Pathol. 42:680-683.

7. Frederickson, D. E., and McLaren, N. W. 2000. Ergot. Pages 40-42 in: Compendium of Sorghum Diseases. 2nd ed. R. A. Frederiksen and G. N. Odvody, eds. American Phytopathological Society, St. Paul, MN.

8. Frederickson, D. E., and Odvody, G. N. 2002. Survival of inoculum of Claviceps africana in Zimbabwe: Potential sources of inoculum. Pages 79-82 in: Sorghum and Millets Diseases. J. F. Leslie, ed. Iowa State University Press, Ames.

9. Griffiths, J., and Bryan, J. 1987. The Climates of Texas Counties. Natural Fibers Information Center, University of Texas, Austin.

10. Hyakumachi, M., and Arora, D. K. 1998. The response of fungal propagules to competitive energy stress in soil. Ann. New York Acad. Sci. 851:152-161

11. Isakeit, T., Odvody, G. N., and Shelby, R. A. 1998. First report of sorghum ergot caused by Claviceps africana in the United States. Plant Dis. 82:592.

12. Jensen, S. G. 1998. Winter survival of Claviceps africana spores in the central plains of the USA. Int. Sorghum Millets Newsl. 39:113-114

13. Komolong, B., Chakraborty, S., Ryley, M., and Yates, D. 2002. Identity and genetic diversity of the sorghum ergot pathogen in Australia. Aust. J. Agric. Res. 53:621-628.

14. Larkin, T. J., and Bomar, G. W. 1983. Climatic Atlas of Texas. Texas Department of Water Resources, Austin.

15. Mantle, P. G., Hassan, H. A. G., and McLaren, N. W. 1999. Putative control of ergot disease epidemics in hybrid sorghum production through the inhibition of secondary sporulation by Claviceps africana. Pages 141-146 in: Proc. Conf. Ergot Sorghum, 1-8 June 1997, Sete Lagos, Brazil. C. R. Casela and J. A. Dahlberg, eds. EMBRAPA/INTSORMIL/ICRISAT Publ. 99-1.

16. Mower, R. L., Gray, G. R., and Ballou, C. E. 1973. Sugars from Sphacelia sorghi honeydew. Carbohydrate Res. 27:119-134.

17. Odvody, G. N., Frederickson, D. E., Isakeit, T., Montes, N., Dahlberg, J. A., and Peterson, G. L. 2002. Quarantine issues arising from contamination of seed with ergot: An update Pages 123-127 in: Sorghum and Millets Diseases. J. F. Leslie, ed. Iowa State University Press, Ames.

18. Odvody, G. N., Montes, N., Frederickson, D. E., and Narro-Sánchez, J. 2002. Detection of sclerotia of Claviceps africana in the western hemisphere. Pages 129-130 in: Sorghum and Millets Diseases. J. F. Leslie, ed. Iowa State University Press, Ames.

19. Paul, E. A., and Clark, F. E. 1989. Soil Microbiology and Biochemistry. Academic Press, San Diego.

20. Pažoutová, S., Bandyopadhyay, R., Frederickson, D. E., Mantle, P. G., and Frederiksen, R. A. 2000. Relations among sorghum ergot isolates from the Americas, Africa, India, and Australia. Plant Dis. 84:437-442.

21. Prom, L. K., and Lopez, J. D., Jr. 2004. Viability of Claviceps africana spores ingested by adult corn earworm moths, Helicoverpa zea (Lepidotpera:Noctuidae). J. Econ. Entomol. 97:764-767.

22. Prom, L. K., Lopez, J. D., Jr., and Latheef, M. A. 2003. Transmission of Claviceps africana spores from diseased to non-infected sorghum by corn earworm moths, Helicoverpa zea. $\mathrm{J}$. Sustain. Agric. 21:49-58.

23. Tooley, P. W., Goley, E. D., Carras, M. M., and O'Neill, N. R. 2002. AFLP comparisons among Claviceps africana isolates from the United States, Mexico, Africa, Australia, India, and Japan. Plant Dis. 86:1247-1252.

24. Workneh, F., and Rush, C. M. 2002. Evaluation of relationships between weather patterns and prevalence of sorghum ergot in the Texas panhandle. Phytopathology 92:659-666. 